\title{
An overview of bimrocks and related engineering geological problems in the Nepal Himalaya
}

\author{
*S. C. Sunuwar ${ }^{1}$, B. N. Upreti ${ }^{2}$, and U. Glawe ${ }^{3}$ \\ ${ }^{1}$ SN Power Holding Singapore Pvt. Ltd, Lalitpur, Nepal \\ ${ }^{2}$ Department of Geology, Tri-Chandra Campus, Tribhuvan University, Ghantaghar, Kathmandu, Nepal \\ ${ }^{3}$ School of Civil Engineering, Asian Institute of Technology, Pathumthani, Thailand \\ (*Email: subas.sunuwar@snpower.com)
}

\begin{abstract}
Rocks falling under the category of bimrocks are common in Nepal and are covering large areas of the country. However, knowledge on their exact distribution is limited, and data on classification and quantification of engineering properties are practically nonexistent. So far, the bimrock terminology is not commonly used for engineering classification of rocks in Nepal. However, three types of bimrocks can be identified in Nepal, they are: cataclastic or shear zone bimrocks, conglomeratic bimrocks and the bimrocks produced by weathering. The thickness of the bimrock strata varies according to the geological and tectonic settings and can reach several kilometres. Due to the relative weakness of bimrocks and the high erodability, they can pose serious problems such as excessive overbreak, water inflow and large rock mass deformations in tunnelling, and slope instabilities in road cuts and other excavations for surface structures. Efforts on the study of bimrocks in Nepal are initiated recently and is considered to help identifying, addressing and solving the associated problems.
\end{abstract}

Keywords: Bimrocks, cataclastic, matrix

Received: December 17, 2009

Revision accepted: April 10, 2010

\section{INTRODUCTION}

The term "block-in-matrix", originally proposed by Raymond (1984) was abbreviated to bim-(rocks) by Medley (1994) and defines "a mixture of relatively large, competent blocks within a bonded matrix of finer and weaker texture". Independent of geological origin (or geological name) many mixed and fragmented predominantly bimodal rock masses classed as bimrocks have similar engineering behaviours and pose similar design and construction problems. In addition colluvium, alluvium and dilluvium have properties and behaviour similar to bimrocks and are called bimsoils.

Rocks falling under the category of bimrocks are common in Nepal. Practically in every Hydropower Project and in every other infrastructure, bimrocks are involved. Until now bimrock terminology is not commonly used in Nepal as such. In engineering practices, only the strength of weaker matrix is generally considered for design purpose, which can lead to a very conservative and costly design. Shear strength of bimrock depends on the volumetric proportion exceeded about 25\% (Medley 1994). It was also discovered that the angle of internal friction increased, cohesion decreased, and the modulus of deformation increased as block volumetric proportion increased to about $75 \%$ volumetric proportion (Medley 1994). Beyond the upper limit of block proportion, blocks tend to touch and the materials are no longer blockin-matrix (for example blocky rock with irregular discontinuity infillings). The strength of the blocks is irrelevant to the overall strength of a bimrock; only the volumetric proportion of blocks is important (Medley 1994). Thus a great field of research is open on the bimrocks of the Himalaya where a large number of hydropower projects with hundreds of kilometers of tunnel and dam foundation work, mountain roads and other infrastructures are being developed rapidly and bound to frequently encounter problematic rocks. For better understanding, in this paper relevant geological structures of the country are briefly introduced.

\section{MAIN STRUCTURAL ELEMENTS OF THE HIMALAYA}

The Himalaya is formed as a result of collision between the Indian Plate and the Eurasian Plate that began around 50 million years ago. Today, the Indian Plate is constantly moving to the north and converges on Tibet (southern edge of the Eurasia) at the rate of $50 \mathrm{~mm} / \mathrm{yr}$. This convergence builds up significant stresses to thrust the Indian Plate underneath the Eurasian Plate and pushing the Himalaya upward at a rate of $2 \mathrm{~mm} / \mathrm{yr}$. It is thus the most active mountain ranges in the world. Hence, it is seismically very 


\section{S. C. Sunuwar et al.}

active and physiographically very rugged and fragile in nature.

Nepal lies in the central sector of the $2500 \mathrm{~km}$ long Himalayan arc (Fig. 1). Geologically, from south to north, Nepal can be divided into the following five major tectonic units (Figs. 2 and 3), namely:

(i) Terai, the northern edge of the Indo-Gangetic Plain (100-200 m. a.s.1.),

(ii) Siwalik (200-2000 m. a.s.l.)

(iii) Lesser Himalaya (300 - 4000 m. a.s.l.),

(iv) Higher or Greater Himalaya (3000 - 7000 m. a.s.1.), and

(v) Tibetan-Tethys Himalaya (3000 - 8000 m. a.s.1.)

The boundaries between these units are intra-crustal thrusts, dipping to the north (Figs. 2 and 3). Only the Higher and the Tibetan-Tethys Himalaya are separated by a normal fault known as the South Tibetan Detachment System (STDS). Each zone has its own characteristic physiography, lithology, metamorphism and tectonic history and structures. The main structural framework of the Himalaya is thus formed by the three northerly inclined major thrusts developed in the upper crust of the Indian Plate. From north to south they are: the Main Central Thrust (MCT), the Main Boundary Thrust (MBT) and the Main Frontal Thrust (MFT) (Figs. 2 and 3). The MFT is the most active structure of the Himalaya followed by the MBT (Fig. 4). Both of these shallow thrusts

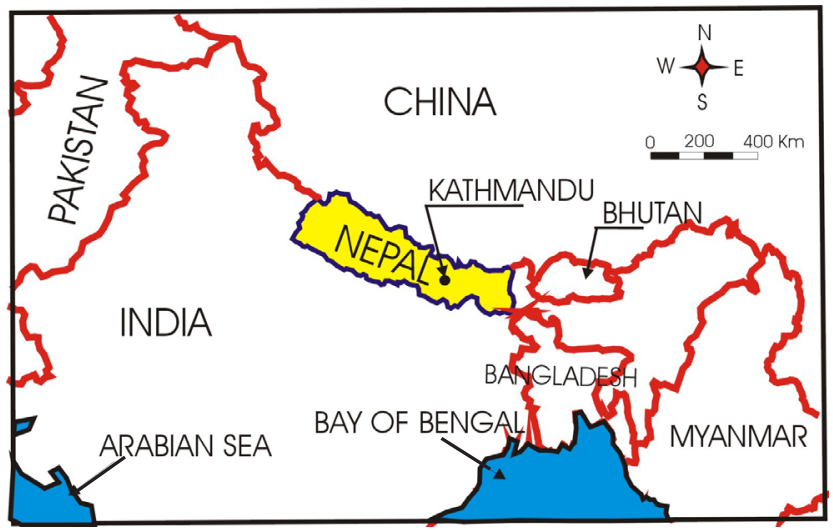

Fig. 1: Location map of Nepal

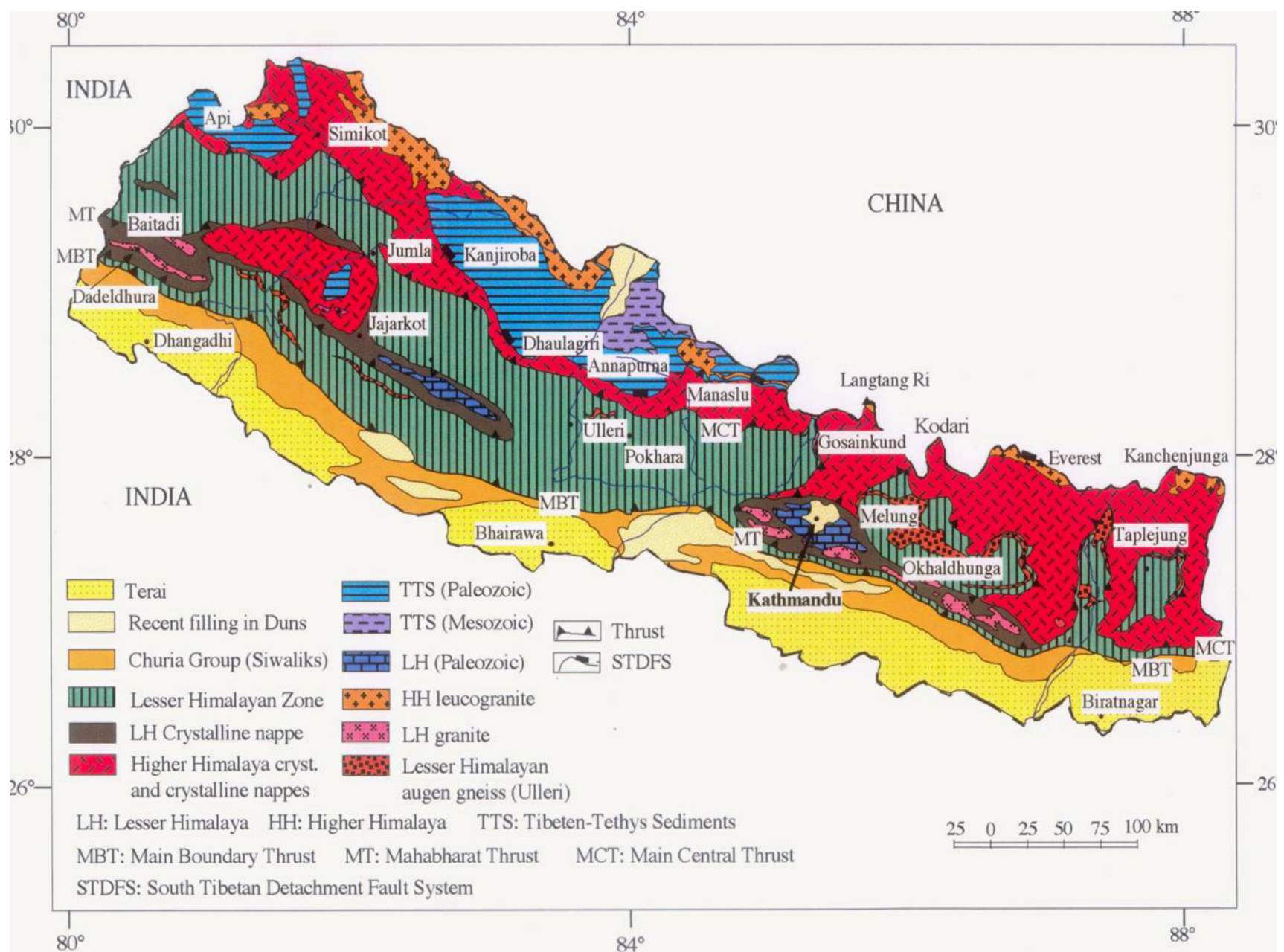

Fig. 2: Geological map of Nepal showing the major thrust and fault systems in the Nepal Himalaya (Upreti and Le Fort 1999) 
$S$

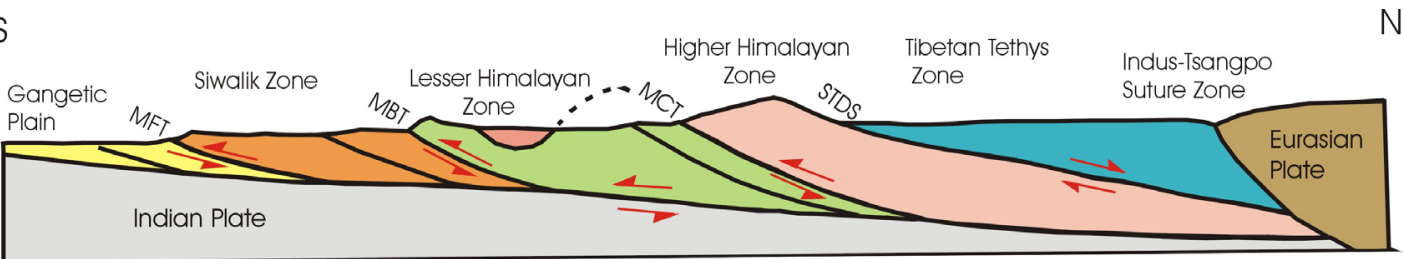

STDS: South Tibetan Detachment System MBT: Main Boundary Thrust

MCT: Main Central Thrust

MFT: Main Frontal Thrust

Fig. 3: Generalised cross-section of the Himalaya showing the major tectonic features of the Nepal Himalaya (Harris and Whalley 2001)

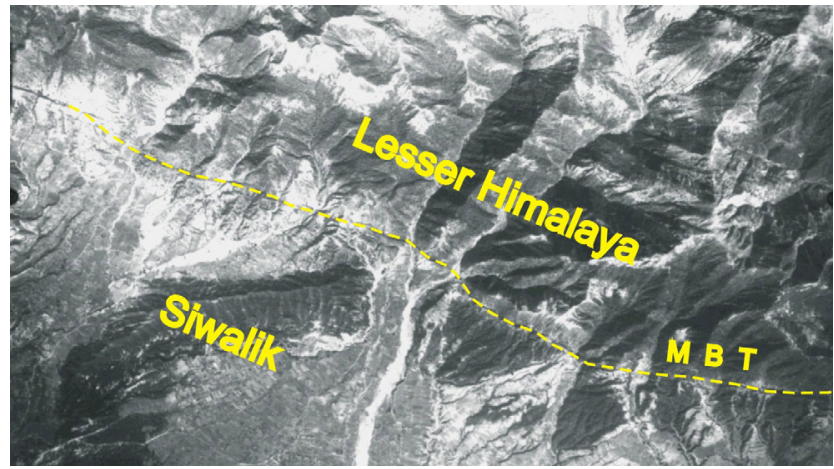

Fig.4: Aerial photograph of western Nepal (north of Dang Valley) showing the trace of the active Main Boundary Thrust (MBT)

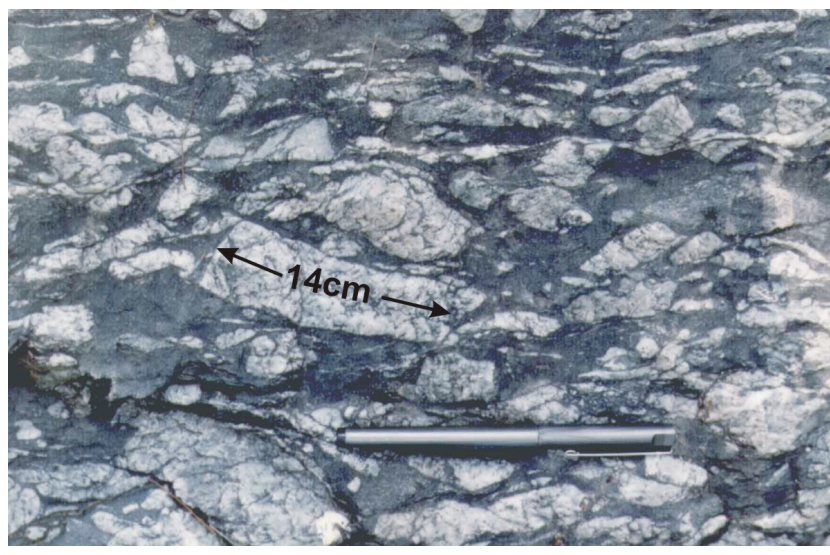

Fig. 6: Shear zone bimrock. It contains about $40 \%$ rectangle and lenticular shaped competent blocks in $60 \%$ weak matrix (Location: north of Dharan Bazaar in eastern Nepal, Lesser Himalaya)

were developed in a predominantly brittle environment. Movement along these mega structures have produced thick shear zones and bimrocks along their entire length.

The MCT is not active today but has developed a few hundred meters to a few kilometres thick shear zone (Upreti and Le Fort 1999). This ductile shear zone had its origin at a deeper crustal level and later brought to the surface by thrusting. The STDS was more or less contemporaneous with the MCT and developed in a varying brittle to ductile

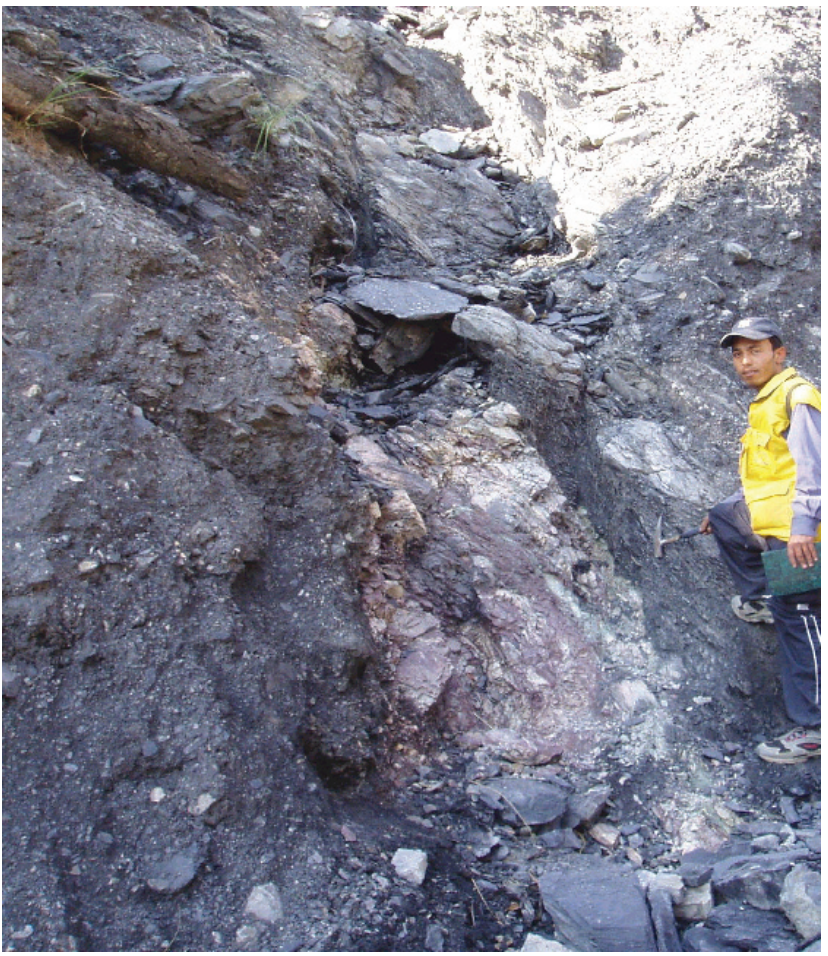

Fig. 5: Cataclastic bimrock along the MBT at Kerabari, western Nepal

environment. In addition to the major tectonic structures described, there are numerous shear zones related to other active and inactive faults, which produced bimrock sequences up to tens of metres in thickness.

\section{BIMROCKS IN NEPAL}

Three types of bimrocks can be identified in the Nepal Himalaya which are summarised below:

\section{Cataclastic or shear zone bimrocks}

Cataclastic or shear zone bimrocks are associated with thrusts and faults. They consist of sheared and crushed rocks with strong or competent predominantly lenticular blocks of various shapes and sizes embedded in a weak fine-grained matrix (Figs. 5 and 6; Table 1). The matrix consists in general of highly sheared, altered and 


\section{S. C. Sunuwar et al.}

Table 1: Types, location, origin and estimated block-size distribution of the bimrocks in Nepal

\begin{tabular}{cccc}
\hline Type & Location and thickness & Origin & $\begin{array}{c}\text { Estimated block-size } \\
\text { distribution }\end{array}$ \\
\hline $\begin{array}{c}\text { Shear Zone } \\
\text { Bimrocks }\end{array}$ & $\begin{array}{c}\text { Major and minor thrusts and faults, up to hundreds of metres in } \\
\text { thickness. (MBT at Kerabari, 60 m thick shear zone in Ale north } \\
\text { of Dharan Bazaar in eastern Nepal Lesser Himalaya) }\end{array}$ & $\begin{array}{c}\text { Product of } \\
\text { shearing }\end{array}$ & $\begin{array}{c}\text { From few centimetres to } \\
\text { few meters }\end{array}$ \\
$\begin{array}{c}\text { Conglomeratic } \\
\text { Bimrocks } \\
\text { Bimrocks } \\
\text { produced by } \\
\text { weathering }\end{array}$ & $\begin{array}{c}\text { Upper Siwalik (few hundreds of meters to few kilometres thick) } \\
\text { and Gondwana diamictitites of Lesser Himalaya (up to hundreds } \\
\text { of metres thick) }\end{array}$ & $\begin{array}{c}\text { Sedimentary } \\
\text { origin }\end{array}$ & $\begin{array}{c}\text { From few to several tens } \\
\text { of centimeters }\end{array}$ \\
\hline
\end{tabular}

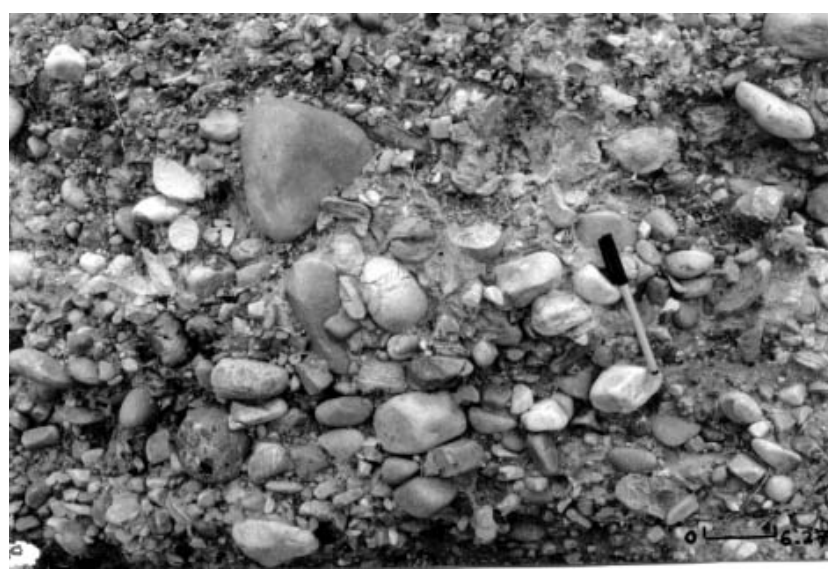

Fig. 7: Conglomeratic bimrocks (Upper Siwalik) showing sub-rounded to well-rounded pebble to boulder size blocks in fine-grained matrix (Location: Dhan Khola, western Nepal)

decomposed clayey silty gouge. Size of blocks varies from few millimetres to few meters. Similarly, experience in Nepal shows that the total volume of blocks generally varies from $10 \%$ to $70 \%$ with respect to the matrix. Generally, they are heterogeneous with widely varying internal structures. Shearing in fine-grained rocks such as phyllites and schists produce high proportion of fine-grained matrix interspersed with competent blocks formed by thick quartz veins and interbedded thin quartzite and other competent rock layers. Shearing in strong and brittle rocks such as quartzite, granite, gneiss, migmatite generates high proportion of strong blocks with low proportion of fine-grained matrix. The strength of rocks varies depending upon the block/matrix ratio (Medley 1994) i.e., higher the block proportions, higher the strength. Due to sub-tropical climate in the lower altitude areas, such bimrocks are invariably affected by strong physico-chemical weathering reaching depths up to few tens of meters.

\section{Conglomeratic bimrocks}

Indurated boulder conglomerates may also be classed as conglomeratic bimrocks (Medley 1994). These bimrocks are formed by sedimentation process in various sedimentary environments (Table 1). The Neogene Upper Siwalik rocks of the Nepal Himalaya predominantly consist of pebbleboulder conglomerate and range in thickness from few hundred meters to over $2 \mathrm{~km}$. The grain size varies from pebbles to boulders in a fine-grained matrix of sand and clay. The materials are generally consolidated and locally cemented by calcite (Fig. 7). This leads to some "cohesive" strength in the rock masses. The volume percent of matrix may range between 15-20 and can be as low as 10\%. Many of the north-south roads in Nepal pass through this zone and create a lot of slope stability problem after exposure of the rock to climatic conditions. So far no underground structures have been built in Nepal in this type of bimrocks. However, it is considered that underground excavation with small spans and in dry conditions may provide reasonable materials for tunnelling, but for larger excavation spans and in particular when water is encountered significant problems may arise.

In addition to the above conglomerates, the Upper Paleozoic to Mesozoic conglomerates and diamictites of Gondwana Group in the Lesser Himalaya also form an important class of bimrocks. The diamictites are of glacial origin. They are matrix-dominated with low proportion of angular to subrounded blocks. The matrix is mainly made up of fine silt and clay.

\section{Bimrock produced by weathering}

This group consists of angular to sub-rounded blocks of varying strength bonded in a fine-grained weak matrix and are commonly found in granitic and gneissic terrains of Nepal. A large number of surface civil structures, mainly roads and dam foundations in Nepal commonly encounter this type of bimrocks. Slope stability problems are the common problem faced in such bimrocks.

\section{EXPERIENCE WITH BIMROCKS IN NEPAL}

Over $70 \mathrm{~km}$ long tunnels have been already built in Nepal primarily for the hydropower projects. Majority of these projects faced serious problems during excavation. Presence of cataclastic or shear zone bimrocks was the main cause for these problems. Projects were significantly delayed and cost 


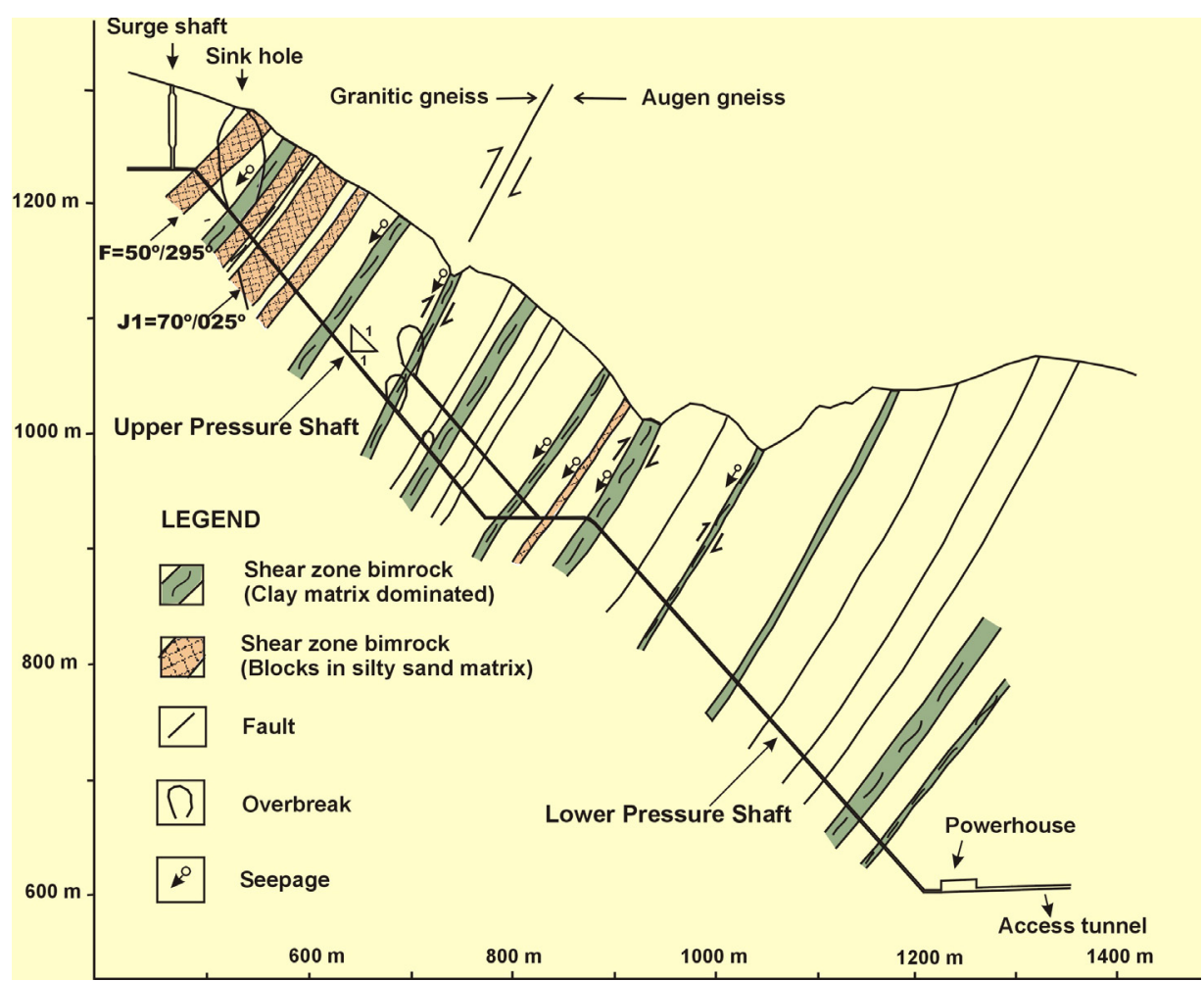

Fig. 8: Geological section along the inclined pressure shaft in Khimti project showing shear zone bimrocks (Sunuwar 2003)

overruns were very high. As almost all the tunnels in Nepal were excavated in metamorphic geological terrains, the following descriptions are focused on bimrocks associated with shear zones. The most common problems related with bimrocks of Nepal are summarized below:

\section{Excessive overbreaks and collapses}

Excessive overbreak and collapses are major problem during excavations of tunnels in the cataclastic or shear zone bimrocks of Nepal. The trigger is primarily the presence of water and the solution of the matrix. The ground water washes out the finer matrix and loosens individual rock blocks. As a result, overbreak occurs in the form of progressive ravelling.

\section{Large deformations}

Large rock mass deformations in underground structures are other common problem in Nepal while tunnelling through shear zone bimrocks. The deformations were experienced to occur, as one would expect when tunnelling in weak rock, but long-term deformation was also observed, indicating a time-dependent behaviour of the encountered rocks. In some case re-profiling and re-supporting of the tunnel was required leading to increase of construction time and costs.

\section{Ground water inflow}

Groundwater inflow is another common problem while excavating tunnels in cataclastic or sheared bimrocks. The bimrock strata are frequently water-bearing as they are often relatively permeable in comparison to the surrounding host rocks.

\section{Slope instability}

Slope instability problems are very common in cataclastic or shear bimrocks due to the high erodability of the matrix materials. In Nepal, major traffic lines are oriented either E$\mathrm{W}$ or N-S. Hence, they are crossing the major bimrock containing tectonic structures. In addition to the high erodability of these rocks, the climatic condition, i.e. the high intensive precipitation in the monsoon season (up to $3000 \mathrm{~mm}$ in 4 months) contributes significantly to this problem.

\section{TUNNELING IN NEPAL'S SHEAR ZONE BIMROCKS: CASE STUDIES}

Two hydropower projects are briefly discussed below to elucidate the problems encountered in the cataclastic or shear zone bimrocks of Nepal.

\section{Khimti Hydropower Project (60 MW)}

This hydropower project lies in central Nepal about 75 $\mathrm{km}$ north east of Kathmandu. The country rocks are gneisses and schists belonging to the Lesser Himalaya (Fig. 8). It has $0.9 \mathrm{~km}$ of access tunnel, $7 \mathrm{~km}$ of headrace tunnel and $1.1 \mathrm{~km}$ of inclined pressure shaft. The problems encountered in the project may be summarised below. 


\section{S. C. Sunuwar et al.}

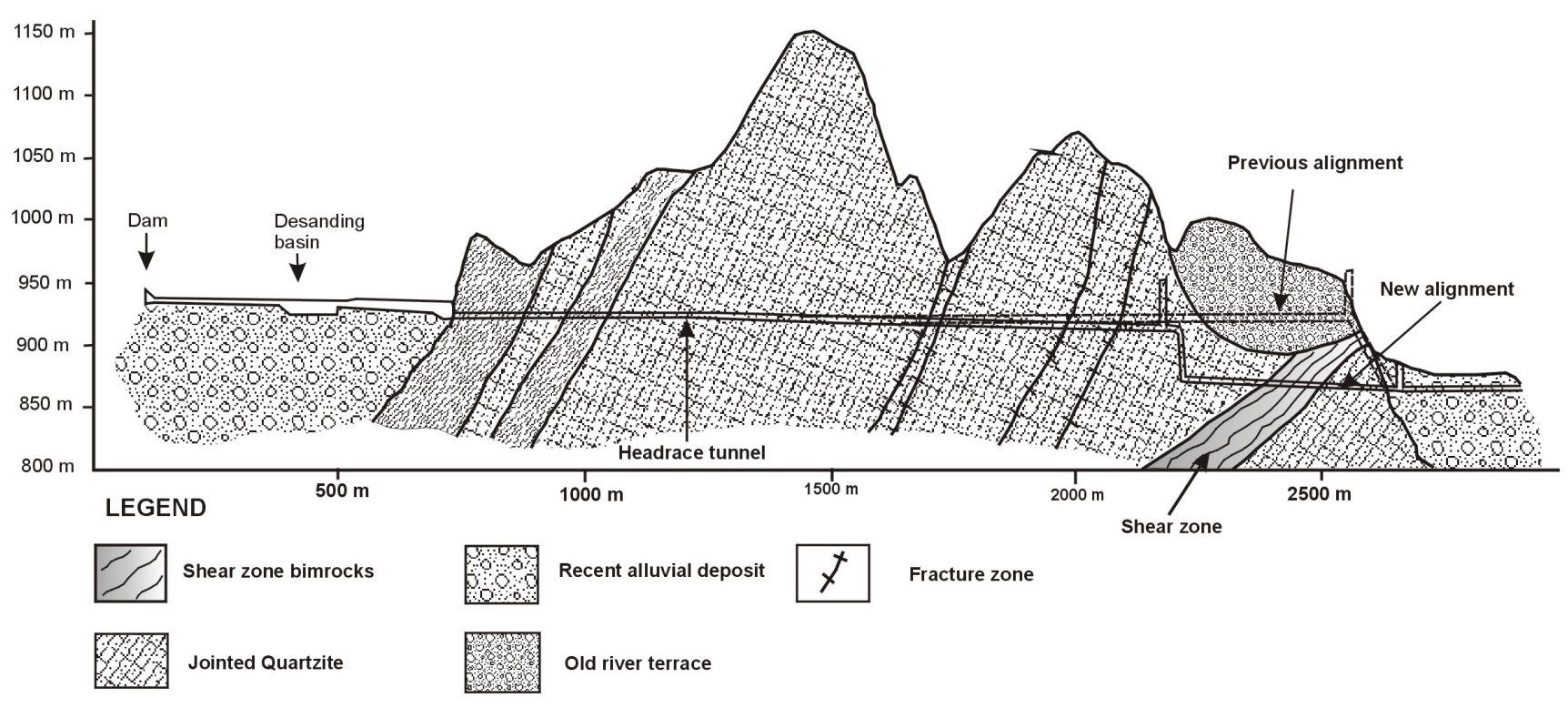

Fig. 9: Geological section along the tunnel alignment, Modi Khola Project (Paudel et al. 1998)

\section{Excessive overbreaks}

Overbreak problems were encountered where the tunnel sections contained cataclastic or shear zone bimrock with considerable amount of seepage. There were 13 major overbreaks (Table 2), all were in cataclastic or sheared bimrocks. These overbreaks delayed the project and also required to change the tunnel alignment, which resulted in an increase of the tunnel length of $20 \%$.

\section{Large deformations}

Large deformations were encountered in shear zone bimrocks during excavation in different sections of the tunnel, which are listed in Table 3. These bimrocks are characterised by sheared and decomposed schist with clay gouge. It contains about $60-70 \%$ non-active clays such as illite and chlorite. The thickness of these sections varies from 5 to a maximum of $60 \mathrm{~m}$. High rock pressure was reflected by shotcrete cracking and sidewall convergences. In some section invert heaving was also observed. However in some sections tunnel deformation was monitored for more than 12 months. In Adit 5 tunnel at chainage $245 \mathrm{~m}$ (Table 3), the maximum deformation measured was $40 \mathrm{~cm}(13 \%$ of the tunnel outer diameter). In Table 3 the Q-values after Barton's rock mass classification are also presented to demonstrate that most of these bimrocks can be classified as being of extremely low quality. However, it was experienced as being extremely difficult to practically apply one of the classic rock mass classifications to bimrocks.

In the problematic tunnel sections progress was very slow, i.e. 7-10 m per week and rock support of $25 \mathrm{~cm}$ thick fibre reinforced shotcrete with grouted rock bolts or in situ concrete lining had to be provided.
Table 2: Major overbreak record of the Khimti Hydropower Project (Sunuwar 2004)

\begin{tabular}{lcc}
\hline \multicolumn{1}{c}{ Location } & $\begin{array}{c}\text { Date of } \\
\text { occurrence }\end{array}$ & $\begin{array}{c}\text { Shear zone } \\
\text { bimrock (total } \\
\text { thickness in m) }\end{array}$ \\
\hline Adit 1 Headrace D/S & 29 Aug. 97 & 30 \\
Ch. 344-363 m & 18 Sept. 97 & 50 \\
Ch. 330-390 m & & \\
Adit 2 Headrace D/S & 12 Aug. 97 & 25 \\
Ch. 230-260 m & 19 Sept. 98 & 20 \\
Adit 3 Ch. 194-210 m & 31 Oct. 98 & 30 \\
Headrace D/S, Ch. 12-26 m & 9 Feb. 95 & 15 \\
Adit 4 (Old) Ch. 44-50 m & 18 Aug. 96 & 20 \\
Adit 4 (New) Ch. 44-50 m & 15 Dec. 94 & 15 \\
Adit 5 Ch. 110-115 m & 19 Apr. 97 & 20 \\
Old upper pressure shaft & & \\
Ch. 186 m onwards & & 35 \\
New upper pressure shaft & & \\
Ch. 352-364 m & 14 Jul. 98 & \\
Tailrace Ch. 129-135 m & 15 Jun. 98 & 20 \\
\hline
\end{tabular}

\section{Ground water inflow}

Excessive water inflow was encountered particularly in the headrace tunnel between Adit 1 and Adit 3. Locally, water ingress was high (50 litres/sec.).

\section{Modi Khola Hydroelectric Project (14 MW)}

The Modi Khola hydroelectric project lies about $250 \mathrm{~km}$ west of Kathmandu. It has a $1.5 \mathrm{~km}$ long headrace tunnel, a $50 \mathrm{~m}$ deep vertical shaft and $351 \mathrm{~m}$ long pressure tunnel. Geologically, the project lies in the Lesser Himalaya and the tunnels mainly pass through quartzite and phyllite. 
Table 3: Examples of large deformations reported from the Khimti Hydropower Project (Sunuwar and Fowell 2001)

\begin{tabular}{lccc}
\hline \multicolumn{1}{c}{ Location } & Q - value & $\begin{array}{c}\text { Deformation } \\
(\mathbf{m m})\end{array}$ & $\begin{array}{c}\text { Shear Zone Bimrock } \\
\text { (Thickness in m) }\end{array}$ \\
\hline $\begin{array}{l}\text { Adit 1 } \\
\text { Headrace D/S, }\end{array}$ & & 60 \\
Ch. 465-620 m & $0.003-0.006$ & $50-170$ & \\
Adit 2 & & \\
Headrace D/S, & & 60 & \\
Ch. 1276-1280 m & 0.03 & & 15 \\
$\begin{array}{l}\text { Adit 3 } \\
\text { Headrace U/S Ch. }\end{array}$ & & & \\
178-234 m & 0.3 & $40-63$ & 18 \\
$\begin{array}{l}\text { Adit 4 (Old) } \\
\text { Ch. 58-76 m }\end{array}$ & 0.004 & $100-300$ & 10 \\
$\begin{array}{l}\text { Adit 5 } \\
\text { Ch. 222-245 m }\end{array}$ & 0.01 & $300-400$ & \\
Tailrace D/S & & & 50 \\
Ch. 68-80 m & $0.3-0.4$ & 2.4 & \\
\hline
\end{tabular}

\section{Excessive overbreaks}

Major problems were encountered at the horizontal pressure tunnel when tunnelling passed through a $32 \mathrm{~m}$ thick shear zone (perpendicular to the shear zone plane), which is indicated in Fig. 9. The bimrock is characterised by fully decomposed soft clay matrix and blocks. The clay matrix consists of more than $80 \%$ non-active clay. The strike of shear zone is at an acute angle to the tunnel axis and the zone provided a high rate of ground water inflow since the pressure tunnel alignment was $7-10 \mathrm{~m}$ below the riverbed level. The tunnel was stabilised by consolidation grouting and steel rib support. Progress was only 2-3 m per week in this section. It required 10 months to complete this $85 \mathrm{~m}$ long bimrock section.

\section{Large deformations}

Large tunnel deformations were also encountered along the horizontal pressure tunnel in the shear zones close to the desanding basin (Fig. 9). The development of significant rock pressure was reflected by buckling of steel sets in the side-walls and occasionally in the crown and by invert heaving. Deformations were observed for 4 months, only, and maximum deformation occured during this period was $150 \mathrm{~cm}$ (30\% of tunnel diameter). Umbrella grouting and steel sets with shotcrete were applied for temporary support. In addition, steel struts and concrete were placed in the invert. The deformed section of the tunnel had to be re-profiled; the original steel sets were replaced and a reinforced concrete liner was provided for final support.

\section{CONCLUSIONS}

Nepal is located in the tectonically very active Himalayan range. Due to its geological and tectonic setting bimrocks are very frequent. Three classes of bimrocks were identified with field thicknesses of up to several kilometres: shear zone bimrocks, conglomeratic bimrocks and bimrocks as a product of weathering. In underground construction works, excessive overbreaks, large deformations and water ingress create frequent problems in the bimrocks of Nepal. Surface excavations in bimrocks are usually associated with slope instabilities.

Currently, the knowledge on the geotechnics and the engineering behaviour of these rock types is very limited in Nepal, despite the fact that most engineering projects in this country have to deal with the encountered problems. Comprehensive geological and engineering geological researches are required to better understand these rock materials and to actually design the up-coming hydropower and infrastructure projects according to the technical requirements of the bimrocks in Nepal.

\section{REFERENCES}

Harris, N. and Whalley, J., 2001, Mountain Building, Block 4. The Open University, U.K., 165 p.

Medley, E. W., 1994, Using stereologic methods to estimate the block volumetric proportion in melanges and similar bloc-inmatrix rocks (bimrocks). In Proc. $7^{\text {th }}$ Congress of the Int. Assoc. Eng. Geol., Lisbon, Portugal. Rotterdam: A. A. Balkema.

Paudel, T. R.; Dangol, V., and Sharma, R. H., 1998, Construction phase engineering geological study in Modi Khola Hydroelectric Project, Parbat district, western Nepal. Jour. Nepal Geol. Soc., v. 18, pp. $343-355$.

Raymond, L. A., 1984, Classification of melanges: in Melanges: Their nature, origin and significance. Spec. pub. 228, Geol. Soc. of America, Boulder, Colorado; pp. 7-20.

Sunuwar, S. C., 2004, Geological problems in the hydropower development of Nepal: Case studies, Seminar Papers Disaster 


\section{S. C. Sunuwar et al.}

Management in Nepal, Nepal Engineers' Association, April 11-12, 2004, Kathmandu, pp. 130-141.

Sunuwar, S. C., 2003, Overbreak problem in the inclined pressure shaft of the Khimti I Hydropower Project in Nepal, World Tunnelling, v. 16, No. 6, pp. 241-242.

Sunuwar, S. C. and Fowell, R. J., 2001., Rock squeezing problems experienced in the Khimti Hydropower Project, Nepal.
Proceedings of the ISRM Regional Symposium Eurock 2001, Espoo, Finland, edited by P Sarkka and P. Eloranta. Pub. A.A Balkema, Lisse, Netherlands, pp. 711-716.

Upreti, B. N. and Le Fort, P., 1999, Lesser Himalayan Crystalline Nappes of Nepal: Problems of their origin. Geol. Soc. Am. Bulletin, Spec. Issue. v. 328, pp. 225-238. 